\title{
EUROPEAN UNION FUNDS IN IT DEPLOYMENT FOR THE POLISH TAX ADMINISTRATION
}

\author{
EDYTA MAŁECKA-ZIEMBIŃSKA
}

Uniwersytet Ekonomiczny w Poznaniu, Wydział Ekonomii, POLAND

e-mail: Edyta.Malecka-Ziembinska@ue.poznan.pl

\begin{abstract}
\begin{tabular}{l|l} 
RECEIVED & 18 January 2018
\end{tabular}
\begin{tabular}{l|l} 
ACCEPTED & 2 September 2018
\end{tabular}

JEL

CLASSIFICATION H21, $\mathrm{H} 26, \mathrm{H} 83$

KEYWORDS European Union funds, IT deployment, tax administration

ABSTRACT The purpose of the article is to define the scope of IT solutions implementation for the Polish tax administration and the level of involvement of European Union funds in this process. The considerations begin an analysis of the strategic European Union documents determining the directions of spending European Union funds under the multiannual financial framework for 2014-2020. As demonstrated by the analysis, extensive support of information technology constantly implemented under the national tax administration involves significant costs. They are only partly covered by the State Treasury, and in the dominant scope they are financed from European Union funds. It can be assumed that without significant European Union funding, the implementation of these projects would not be possible. Their implementation is, however, necessary, as it determines the efficient and effective operation of the tax administration.
\end{abstract}

\section{Introduction}

In recent years, tax administration in Poland has undergone a number of transformations of organizational and functional nature, aimed at increasing the efficiency and effectiveness of its operations. One of the areas of these changes is the IT implementation of these services, which is part of the integrated activities aimed at improving the functioning of public administration and, consequently, the functioning of the state. The use of modern information 
tools and techniques, including tax administration, also contributes to the pursuit of sustainable state development. The purpose of the article is therefore to define the scope of IT deployment for the Polish tax administration and the degree of involvement of European Union (EU) funds in this process.

\section{IT implementation for public adminisitration in Poland and the European Union}

The EU needs to enhance the efficiency of public expenditure, and find new, untapped sources of growth and employment. Modernising of public administrations is a way to relieve economic and budgetary pressures, to design and deliver needed structural reforms, to remove existing barriers in the Single Market, to foster innovation and create new job opportunities (European Commission, 2016). The key element of this modernization is implementation of IT solutions, because the civilization breakthrough is associated with changes occurring in society, aimed at increasing the level of computerization of society (Ziemba, 2013, p. 401).

In the Europe 2020 strategy adopted by the European Commission on 3 March 2010 under the seven flagship initiatives, a Digital Agenda for Europe was highlighted. It is a project for popularizing high-speed Internet and enabling households and enterprises to take advantage of the digital single market (European Commission, 2010). The Europe 2020 strategy together with its seven flagship initiatives is a reference for co-financing all projects on both the "domestic" and "community" sides in the financial framework for 2014-2020.

In 2015, the European Commission published a new key European strategy, which is the Digital Single Market (European Commission, 2015). The strategy sets out initiatives to make the European Union a digitally integrated economic area capable of competing on the global digital market. One of the highlighted initiatives is e-administration. Electronic public services are an important factor increasing not only the cost-effectiveness, but also the quality of services provided to citizens and enterprises. One example of increased efficiency is the "once only" principle. The public administrations in the EU reuse information about the citizen or companies that is already in their possession without asking again only in $48 \%$ of cases. The extension of this principle, in compliance with data protection legislation, would generate an annual net saving at the EU level of around EUR 5 billion per year (European Commission, 2015).

Actions taken in Poland in the area of public administration meet the objectives set at the European level. The availability, scope and quality of electronic public administration services is gradually increasing. Although the level of development of e-government in Poland is gradually increasing, it still belongs to the lower in the European Union. According to the data of the UN E-Government Survey 2016, the E-Government Development Index ${ }^{1}$ in 2016 amounted to 0.721 for Poland (compared to 0.644 in 2012 and 0.558 in 2010) and it placed our country on the 36th position out of 193 surveyed countries, while in the EU it located our country on the 18th position (promotion by 6 positions compared to 2012) (the index level for the best rated in the EU of Great Britain was 0.919) (United Nations, 2016). In turn, according to Eurostat (2017) for 2016, less than every third Poles (30\%) used Internet to interact with public authorities. For comparison, in the entire European Union almost half (48\%) of EU citizens use e-government, and in Denmark, Finland and Sweden about or over $80 \%$ (Table 1).

\footnotetext{
${ }^{1}$ The measurement of the E-Government Development Index is the effect of a weighted average of several scales corresponding to the main dimensions of e-government: 1) the scope and quality of online services; 2) the level of use of the telecommunications infrastructure; 3) the level of human capital.
} 
Tahle 1. Internet use in contacts with public administration, EU, Iceland, Norway and Switzerland, 2008-2016 (\% of all individuals)

\begin{tabular}{|c|c|c|c|c|c|c|c|c|c|c|}
\hline State & 2008 & 2009 & 2010 & 2011 & 2012 & 2013 & 2014 & 2015 & 2016 & $\begin{array}{c}2016-2008 \\
\text { (percentage points) }\end{array}$ \\
\hline EU-28 & 35 & 37 & 41 & 41 & 44 & 41 & 47 & 46 & 48 & 13 \\
\hline EU-15 & 38 & 42 & 45 & 44 & 47 & 47 & 51 & 51 & 53 & 15 \\
\hline Euro area & 37 & 39 & 43 & 44 & 46 & 46 & 50 & 50 & 52 & 15 \\
\hline Latvia & 20 & 30 & 40 & 41 & 47 & 35 & 54 & 52 & 69 & 49 \\
\hline Estonia & 37 & 46 & 50 & 53 & 54 & 48 & 51 & 81 & 77 & 40 \\
\hline Denmark & 49 & 73 & 78 & 81 & 83 & 85 & 84 & 88 & 88 & 39 \\
\hline Greece & 13 & 14 & 16 & 27 & 34 & 36 & 45 & 46 & 49 & 36 \\
\hline Belgium & 26 & 41 & 45 & 47 & 50 & 50 & 55 & 52 & 55 & 29 \\
\hline Portugal & 19 & 21 & 26 & 37 & 39 & 38 & 41 & 43 & 45 & 26 \\
\hline Lithuania & 22 & 22 & 24 & 29 & 36 & 34 & 41 & 44 & 45 & 23 \\
\hline Croatia & 16 & 17 & 19 & 17 & 26 & 25 & 32 & 35 & 36 & 20 \\
\hline Cyprus & 18 & 24 & 25 & 29 & 30 & 30 & 41 & 34 & 38 & 20 \\
\hline Hungary & 28 & 30 & 34 & 38 & 42 & 37 & 49 & 42 & 48 & 20 \\
\hline Finland & 62 & 64 & 68 & 68 & 70 & 69 & 80 & 79 & 82 & 20 \\
\hline Spain & 31 & 34 & 38 & 38 & 44 & 44 & 49 & 49 & 50 & 19 \\
\hline Malta & 25 & 34 & 37 & 37 & 41 & 32 & 40 & 42 & 44 & 19 \\
\hline Sweden & 59 & 65 & 68 & 74 & 78 & 78 & 81 & 73 & 78 & 19 \\
\hline Ireland & 34 & 37 & 37 & 44 & 49 & 45 & 51 & 50 & 52 & 18 \\
\hline France & 48 & 47 & 57 & 57 & 61 & 60 & 64 & 63 & 66 & 18 \\
\hline Czech Republic & 19 & 26 & 23 & 42 & 30 & 29 & 37 & 32 & 36 & 17 \\
\hline Luxembourg & 60 & 66 & 67 & 60 & 61 & 56 & 67 & 70 & 76 & 16 \\
\hline Netherlands & 61 & 61 & 64 & 62 & 67 & 79 & 75 & 75 & 76 & 15 \\
\hline United Kingdom & 40 & 48 & 48 & 40 & 43 & 41 & 51 & 49 & 53 & 13 \\
\hline Norway & 72 & 74 & 76 & 78 & 78 & 76 & 82 & 81 & 85 & 13 \\
\hline Germany & 44 & 48 & 50 & 50 & 51 & 49 & 53 & 53 & 55 & 11 \\
\hline Slovenia & 35 & 35 & 44 & 46 & 48 & 52 & 53 & 45 & 45 & 10 \\
\hline Bulgaria & 10 & 11 & 24 & 25 & 27 & 23 & 21 & 18 & 19 & 9 \\
\hline Austria & 51 & 49 & 51 & 51 & 53 & 54 & 59 & 57 & 60 & 9 \\
\hline Poland & 22 & 25 & 28 & 28 & 32 & 23 & 27 & 27 & 30 & 8 \\
\hline Slovakia & 40 & 38 & 50 & 48 & 42 & 33 & 57 & 51 & 48 & 8 \\
\hline Italy & 20 & 21 & 23 & 22 & 19 & 21 & 23 & 24 & 24 & 4 \\
\hline Romania & $:$ & 7 & 8 & 7 & 31 & 5 & 10 & 11 & 9 & $:$ \\
\hline Iceland & 74 & 80 & 82 & 84 & 86 & 81 & 85 & $:$ & $:$ & : \\
\hline Switzerland & $:$ & $:$ & $:$ & $:$ & $:$ & $:$ & 71 & : & : & : \\
\hline
\end{tabular}

States ranked by the largest increase in the part of the society using the Internet in contacts with public administration.

Source: Eurostat (2017).

Looking at the reasons for using e-government websites (Figure 1), 44\% of e-government users in the EU reported declaration of income tax, followed by requesting personal documents (e.g. passport, ID card or driver's licence) or certificates of birth, marriage or death (20\%), claims for social security benefits (16\%), searching public libraries (16\%), enrolment in higher education or university (9\%) and notification of change of address $(6 \%)$. 


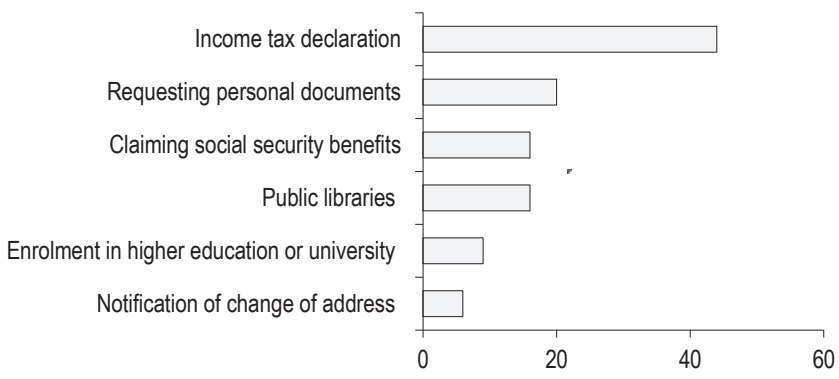

Note: EU-28 without Croatia.

Figure 1. Reasons for using e-government websites, EU-28, 2013 (\% of e-government users)

Source: own work based on Eurostat (2013).

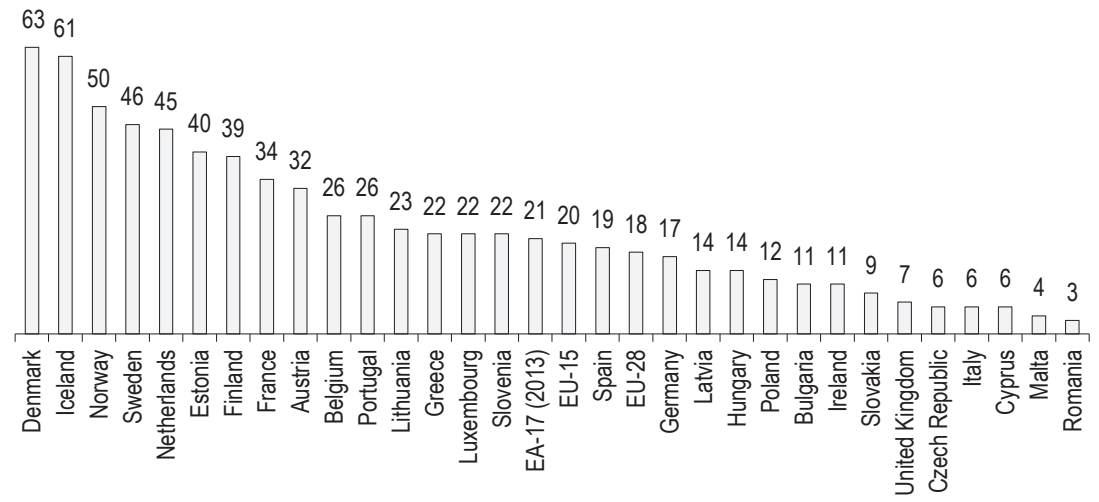

Figure 2. Individuals submitting income tax declaration via websites of public authorities, EU, Iceland and Norway, 2013 (\% of all individuals)

Source: own work based on Eurostat (2017).

In 2013 (unfortunately, Eurostat does not publish later data) in Poland, only 12\% of taxpayers filed an income tax declaration via websites of public authorities. For comparison, there were over $60 \%$ of such taxpayers in Denmark and Iceland. It is worth emphasizing, that in Poland the interest in electronic declarations is growing very fast and in 2017 the number of electronic income tax declarations exceeded $50 \%$ of all submitted declarations.

Poland has been computerizing intensively for nearly a decade. In the previous EU financial perspective (2007-2013), about PLN 4 billion was spent on this purpose. Funds for computerization, however, were spent irrational and inefficient, and the law was not conducive to the effective use of IT systems. According to the diagnosis presented in the "Efficient State 2020" strategy, apart from the attempt to integrate electronic services into ePUAP, there is a lack of universal platform to integrate IT systems. Domain systems dominate, operating in separation from others. The low level of interoperability is a key problem to be solved (Efficient State Strategy 2020, p. 14). The current errors of IT implementation include: (Ministerstwo Cyfryzacji, 2016, pp. 10-22): 
- state information resources are closed to citizens,

- the data collected is not reused,

- the same information is collected in parallel and reproduced,

- systems and registers are not interoperable and compatible,

- the same problems are solved with the help of various tools,

- IT resource management is scattered and decentralized, and thus uncoordinated,

- lack of sufficient competence on the part of administration in the scope of ordering, designing, building IT systems and their maintenance causes delays in implementation, low quality and may cause unreasonable costs for the state; this applies to cooperation with both external and internal suppliers,

- lack of uniform standards and guidelines for the development, maintenance and implementation of ICT projects and cyclical controls,

- lack of effective cooperation of public administration with the private sector,

- lack of state (group, common for part of administration) rules of running IT projects and a leader responsible for coordinating these works.

The problem is also the lack of confidence of Poles in this form of dealing with matters. To increase the popularity of using e-services offered in offices, public administration (the Minister of Digitization and local government bodies) should undertake large-scale information and promotion activities in this area (NIK, 2016).

The Integrated State Informatisation Program (ISIP), which was updated in October 2016, describes the government's efforts to provide high quality public electronic services. The aim of the program is to create a coherent, logical and efficient state information system, effectively providing e-services at the national and European level in terms of quality and costs. The program will ensure cooperation between existing and new ICT systems of public administration, eliminating at the same time duplicate functionalities. Fulfilling the ISIP objectives will be measured by the percentage of citizens and entrepreneurs using e-services of public administration and the level of user satisfaction.

The main source of financing the construction of systems ensuring access to key public administration e-services identified in ISIP will be the Operational Programme Digital Poland (OP DP). Supplementary sources, if possible, will be OP Knowledge, Education and Development, the Connecting Europe Facility, a program for interoperability solutions for European public administrations (ISA) and the Horizon 2020 program.

It is expected that public (national and EU) funds under the second axis of the OP DP will be about EUR 1.1 billion, and public (national and EU) funds involved at the regional level - about EUR 1.8 billion. The difference between the expenditures necessary for the implementation of ISIP and the funds provided for the implementation of OP DP and regional programs will be covered from the budgets of the ministries and budgets of local government units (Ministerstwo Cyfryzacji, 2016, pp. 10-22).

\section{IT implementation for the tax administration in Poland}

Table 2 presents the characteristics, including the scale of co-financing from EU funds, the largest e-projects for the Polish tax administration.

A huge e-project is also the Platform of Electronic Tax and Custom Services (PETCS), which is a continuation of the Electronic Services Platform of the Customs Service launched in 2015. Further modernization of this program is planned. In August 2017, an application for co-financing the PETCS from the resources of the Operational 
Programme Digital Poland in the 3-year implementation period from February 1, 2018 to January 31, 2021 was submitted to the Digital Poland Project Center. The total value of the co-financing awarded amounted to almost PLN 143.4 million (Ministerstwo Finansów, 2018b).

Table 2. The largest e-projects of the Polish tax administration

\begin{tabular}{|c|c|c|c|c|}
\hline Project & Main (strategic) goal & $\begin{array}{c}\text { Period } \\
\text { of implementation }\end{array}$ & $\begin{array}{l}\text { Total cost } \\
(\mathrm{PLN} \mathrm{m})\end{array}$ & $\begin{array}{l}\text { Co-financing } \\
\text { by the EU }\end{array}$ \\
\hline e-Declarations 2 & $\begin{array}{l}\text { streamlining (optimizing) information exchange processes be- } \\
\text { tween the tax administration and its stakeholders }\end{array}$ & $2009-2015$ & 90.4 & OP-IE - $85 \%$ \\
\hline e-Taxes & $\begin{array}{l}\text { simplifying the tax collection system by streamlining (optimiz- } \\
\text { ing) the internal business processes of the tax administration }\end{array}$ & 2009-2015 & 150.7 & OP-IE $-85 \%$ \\
\hline e-Registration & $\begin{array}{l}\text { streamlining (optimizing) the processes of registering taxpay- } \\
\text { ers and payers }\end{array}$ & 2009-2013 & 40.2 & OP-IE $-85 \%$ \\
\hline CVP & $\begin{array}{l}\text { is a continuation of the e-Taxes Program; assumes the launch } \\
\text { and development of digital services in the Ministry of Finance } \\
\text { in the scope of centralization of the service of corporate } \\
\text { income tax (CIT), value added tax (VAT) and the operation } \\
\text { of the Uniform Audit File in order to improve control activities }\end{array}$ & 2016-2019 & 97.6 & OP-DP $-85 \%$ \\
\hline
\end{tabular}

OP-IE - Operational Programme Innovative Economy.

OP-DP - Operational Programme Digital Poland.

Source: own work based on Ministerstwo Finansów (2018a).

Implemented within the national tax administration, extensive support of information technology involves significant costs. In part, they are covered by the State Treasury and, to the extent predominant, they are financed from EU funds. It can be assumed that without significant EU funding, the implementation of these projects would not be possible.

The rationale for these expenditures is to limit the size of budget losses due to tax fraud. An additional premise are examples of supporting the efficiency of tax administrations of other countries through technological solutions, e.g. the ZAUBER (Germany) and VRT or FEAST (Great Britain) (Uzasadnienie do ustawy..., 2016, pp. 2-5).

The estimates of the tax gap published in recent years in Poland, in particular regarding VAT, indicate its high level (Małecka-Ziembińska, 2017, pp. 45-60). Taxpayers falling into the usual business problems related to the loss of liquidity are much less important in its creation. The most important are criminal groups operating outside the law. The measure to combat this crime is to increase the efficiency of tax audits and to enforce fraudulent or unpaid tax amounts. However, this is not possible without providing tax authorities with appropriate IT tools providing in real time information on potential fraud (e.g. central register of invoices). In the European Union, dedicated IT systems for VAT have implemented, among others, Portugal, Slovakia, the Netherlands and Great Britain. From the examples given, it is worth emphasizing the case of Portugal, which implemented a comprehensive system of e-invoices in 2012 and 2013. The Portuguese solution provides, among others, sending a copy of electronic invoices in real time by taxpayers to tax administration servers, which allows them to identify irregularities on an ongoing basis, including disappearing taxpayer. Invoicing takes place only through certified software (Uzasadnienie do ustawy..., 2016, pp. 2-5).

Creating IT systems that support the detection of tax fraud requires not only financing but also adequate legal conditions. For this purpose, in 2016, the Act on specific rules for performing certain tasks in the field 
of computerization of the activities of the National Fiscal Administration bodies was adopted (Ustawa z 29 kwietnia 2016). The Act entered into force on June 12, 2016. It creates the legal basis for setting up a limited liability company, which is a special purpose vehicle. The rationale for this solution is - on the one hand - the application of business management solutions common in the implementation of this type of IT projects in the private sector. It involves efficient implementation of projects using the entity's own resources or with the participation of cooperators of recognized reputation. On the other hand - this solution ensures information security of concepts and solutions designed in systems (Uzasadnienie do ustawy..., 2016, pp. 2-5).

\section{Conclusions}

A well organized tax administration determines an effective and efficient dimension and tax collection. It must be equipped with appropriate IT technologies in the globalization conditions of the Internet age. They are very expensive but necessary. Their lack may result in greater budget losses due to tax fraud. The EU funds play a key role in the computerization of public administration, including tax administration, in Poland. It is extremely important to draw conclusions from previous negative experiences in the field of computerization of public administration and to avoid duplication of errors. The next EU multiannual financial framework may not be so beneficial for Poland.

\section{Referenceses}

Efficient State Strategy 2020, Appendix to Resolution No. 17 of the Council of Ministers of 12 February 2013, 14.

European Commission (2016). Quality of Public Administration, European Semester Thematic Factsheet. Retrieved from: https:/l ec.europa.eu/info/files/european-semester-thematic-factsheet-quality-public-administration-2016_en.

European Commission (2010). Europe 2020 A strategy for smart, sustainable and inclusive growth. Brussels, KOM (2010) 2020, 6.

European Commission (2015). A Digital Single Market Strategy for Europe. Brussels, COM (2015) 192 final, 16.

Eurostat (2013). Statistics Explained. Retrieved from: http://ec.europa.eu/eurostat/statistics-explained/index.php/File:Reasons_for_ using_e-government_websites,_EU-28,_2013_(\%25_of_e-government_users)6.jpg.

Eurostat (2017). E-government activities of individuals via websites. Retrieved from: http://appsso.eurostat.ec.europa.eu/nui/show.do.

Małecka-Ziembińska, E. (2017). Luka w podatku od towarów i usług oraz sposoby jej ograniczania. Kwartalnik Kolegium EkonomicznoSpołecznego. Studia i Prace, 1 (29), 45-60.

Ministerstwo Cyfryzacji (2016). Program Zintegrowanej Informatyzacji Państwa. Wersja zaktualizowana: październik 2016 r., Warszawa, $10-22$.

Ministerstwo Finansów (2018a). Program e-Podatki. Retrieved from: www.epodatki.mf.gov.pl.

Ministerstwo Finansów (2018b). Program PUESC. Retrieved from: www.mf.gov.pl/pl//krajowa-administracja-skarbowa/e-administracja/ projekty.

NIK (2016). Świadczenie usług publicznych w formie elektronicznej na przykładzie wybranych jednostek samorządu terytorialnego. Warszawa, Nr ewid. 223/2015/P/15/003/KAP, 14.

United Nations (2016). UN E-Government Survey 2016. Retrieved from: https://publicadministration.un.org/egovkb/Data-Center.

Ustawa z dnia 29 kwietnia 2016 r. o szczególnych zasadach wykonywania niektórych zadań z zakresu informatyzacji działalności organów Krajowej Administracji Skarbowej, Dz.U. 2016, poz. 781 ze zm.

Uzasadnienie do ustawy z dnia 29 kwietnia 2016 r. o szczególnych zasadach wykonywania niektórych zadań z zakresu informatyzacji działalności organów Krajowej Administracji Skarbowej, 2-5.

Ziemba, E. (2013). Ku zrównoważonemu społeczeństwu informacyjnemu. Roczniki Kolegium Analiz Ekonomicznych, 29, 401.

Cite this article aS: Małecka-Ziembińska, E. (2018). European Union funds in IT deployment for the Polish tax administration. European Journal of Service Management, 3 (27/2), 263-269. DOI: 10.18276/ejsm.2018.27/2-32. 